\title{
Cultivated species sensibility to aqueous extract of Eragrostis plana with high total phenolic content
}

\section{Sensibilidade de espécies cultivadas ao extrato aquoso de Eragrostis plana com elevado conteúdo de fenólicos totais}

Henrique von Hertwig Bittencourt Universidade Federal da Fronteira Sul

E-mail: henrique.bittencourt@uffs.edu.br OrcID: https://orcid.org/0000-0003-1324-382X

Lisandro Tomas da Silva Bonome Universidade Federal da Fronteira Sul

E-mail: lisandro.bonome@uffs.edu.br OrcID: https://orcid.org/0000-0002-4144-3014

Michelangelo Muzell Trezzi Universidade Tecnológica Federal do Paraná

E-mail: trezzim@gmail.com

OrclD: https://orcid.org/0000-0003-3100-0639

Thiago Bitencourt

Universidade Federal da Fronteira Sul

E-mail: bitencourt@uffs.edu.br

OrclD: https://orcid.org/0000-0002-6420-186X

Fortunato de Bortoli Pagnoncelli Junior Universidade Tecnológica Federal do Paraná

E-mail: fpagnoncelli@outlook.com

OrcID: https://orcid.org/0000-0002-8082-6288

Diogo José Siqueira

Universidade Federal da Fronteira Sul

E-mail: diogo.siqueira@uffs.edu.br

OrclD: https://orcid.org/0000-0001-7750-4539

\begin{abstract}
Eragrostis plana is one of the most invasive alien species in pasture lands of southern South America, due to its biological and ecological characteristics. The objectives of the present work were to quantify the total phenols in an aqueous extract from incubated dry matter of $E$. plana shoots and to evaluate its effect on seed germination and seedling development of three cultivated species. The amount of total phenols present in the aqueous extract of the degraded biomass was approximately $0.75 \mathrm{~g} \mathrm{~L}^{-1}$, which is equivalent to $1.35 \%$ of the dry mass of the shoots. Alfalfa was the species that showed greater sensitivity to the aqueous extract, being impaired in both germination and seedling development. Palisade grass and wheat were harmed only during seedling development. Palisade grass was the only species that benefited from the aqueous extract, presenting a smaller number of abnormal seedlings. More studies are needed to characterize the allelochemicals present in the aqueous extract of $E$. plana phytomass, its release rate, and its behavior in soils of infested areas.
\end{abstract}

Keywords: Urochloa brizantha cv. Marandu; Medicago sativa cv. Monarca; Triticum aestivum cv. IPR Catuara; Phytochemical ecology; Allelopathy. 
Resumo: Eragrostis plana é uma das espécies alóctones com maior potencial invasivo nas áreas de pastagem natural do Sul da América do Sul, devido suas características biológicas e ecológicas. Os objetivos desse trabalho foram quantificar os fenóis totais presentes no extrato aquoso de extratos de parte aérea incubada de $E$. plana e avaliar o seu efeito na germinação e no desenvolvimento de plântulas de três espécies cultivadas. A quantidade total de fenóis presentes no extrato aquoso da biomassa degradada foi de aproximadamente $0,75 \mathrm{~g} \mathrm{~L}^{-1}$, o que equivale a $1,35 \%$ da massa seca da parte aérea das plantas. A alfafa foi a espécie com maior sensibilidade ao estrato aquoso, tendo tanto a germinação quanto o desenvolvimento de plântula inibidos. Braquiária brizanta e trigo sofreram apenas no desenvolvimento das plântulas. Braquiária brizanta foi a única espécie que se beneficiou do extrato aquoso, apresentando menor número de plântulas anormais. Mais estudos são necessários para caracterizar os aleloquímicos presentes no extrato aquoso da fitomassa de E. plana, sua taxa de liberação e seu comportamento no solo de áreas infestadas.

Palavras-chave: Urochloa brizantha cv. Marandu; Medicago sativa cv. Monarca; Triticum aestivum cv. IPR Catuara; Ecologia fitoquímica; Alelopatia.

Data de recebimento: $28 / 10 / 2019$

Data de aprovação: 21/07/2020

DOI: https://doi.org/10.30612/agrarian.v13i50.10582

\section{Introduction}

South African lovegrass (Eragrostis plana Nees) is one of approximately 400 species described in its genus (CLAYTON et al., 2002). It is a plant of the Poaceae family and subfamily Chloridoideae, with a perennial life cycle, that reproduces by seeds. Originating in the African continent, it was accidentally introduced to Brazil, where it was disseminated as a forage in the southern region of the country for some years in the 1970s, before being banned. In 1979, it was categorized as an invasive and difficult to eradicate plant and therefore its commercialization and cultivation were forbidden in Brazil.

Even after being classified as an invasive plant, South African lovegrass has increased the invaded area, with a preference for sites without soil mechanization, such as natural pasturelands, cultivated pastures and road borders. After invading agroecosystems, South African lovegrass usually becomes the main population of the plant community. Part of this dominance is attributed to the species' well-developed defense and preservation mechanisms, such as high competitiveness for water, light and nutrients, high seed production with high viability, great dissemination power and low consumption by animals (BITTENCOURT et al., 2017; ZENNI \& ZILLER, 2011). The species also presents anatomical and histochemical characteristics that explain its persistence in stress situations (FAVARETTO et al., 2015).

In addition to the features that make it an excellent competitor, it is theorized that the South African lovegrass uses its specialized metabolism to produce allelochemicals. From the moment these substances are released into the environment by the producing plants, they can meet target plants, limiting their germination and development. This feature, which is common in invasive plants, has been observed in other species and may occur simultaneously with competition for resources (HIERRO \& CALLAWAY, 2003). A part of this trait has already been evaluated in previous work on the effect of South African lovegrass extracts on forages (FERREIRA et al., 2008). However, the number of studies on the phytochemical ecology of South African lovegrass are rare, both in phytotoxicity bioassays and in the identification and quantification of allelochemicals.

Allelochemicals can be classified according to their chemical characteristic, pathways of biosynthesis, or mechanism of action in the target plant. Phenols are known as one of the largest classes of allelopathic compounds (LI et al., 2010), and many of the allelopathic activities of grasses are attributed to this class of compounds (MACÍAS et al., 2007). Phenolic compounds are known to have a hydroxyl-linked benzene ring and are involved in many plant defense mechanisms. They are synthesized in the plants by the shikimic acid pathway from phenylalanine, by the enzyme phenylalanine ammonia lyase (PAL) (TAIZ et al., 2017). Because some studies have already identified an inverse correlation between the concentration of total phenols in extracts of plants and the seedling development of target species, there is the possibility that phenols also explain South African lovegrass phytotoxicity (AN et al., 2001).

At least six distinct mechanisms of action of phenolic compounds on target plants are known, and all have some impact on initial development. They can modify the permeability of the membrane and inhibit the 
absorption of nutrients, as was reported for benzoic and cinnamic acids. Division and cell elongation may be inhibited by coumarin. Caffeic, ferulic, coumaric, cinnamic, vanillic and benzoic acids may influence photosynthesis and respiration. The function and activity of enzymes can be modified by ferulic, caffeic and tannic acids. The synthesis of endogenous hormones can be affected by benzoic acid and polyphenols, which influence the decomposition of indoleacetic acid and gibberellin. Finally, they may also alter protein synthesis, as several phenolic compounds reduce the integrity of DNA and RNA (LI et al., 2010).

Unlike other classes of chemical compounds with allelopathic properties, most phenols are water soluble. This characteristic can facilitate transport from the producing plant to the target plant, as well as its transport inside the plant after being absorbed (CHOU \& LEU, 1992). Moreover, the simultaneous occurrence of other substances with phenols or combinations of different phenols can cause synergistic effects, increasing the allelopathic action of these compounds even when present in low concentrations (AL HARUN et al., 2015; MACÍAS et al., 2004). Therefore, the determination of total phenols constitutes a major step in determining the allelopathic potential of plants (INDERJIT, 1996).

Chemical characteristics of the allelochemical and its concentration in the environment are essential to determine the negative interaction potential, but its dynamics of release into the environment is also a keystone. Plants producing allelochemicals can liberate these compounds actively or by the degradation of their tissues.

Many studies evaluating the allelopathic effect of compounds produced by plants are conducted under artificial conditions, intended to isolate the activity of a given substance and test its phytotoxicity. Because they are developed using techniques and methodologies that are different from the environmental conditions observed in the field, they are often criticized. On the other hand, studies conducted exclusively in the field are influenced by many factors, often constituting complex interactions that are difficult to isolate. Therefore, it seems that a combination of the accuracy and ease of laboratory assays with the realism of field experiment methodologies is needed.

The objectives of this work were to quantify total phenols and to determine the phytotoxicity of the aqueous extract of the aerial part of South African lovegrass infesting range lands of South Brazil in the germination and seedling development of alfalfa (Medicago sativa cv. Monarca), palisade grass (Urochloa brizantha cv. Marandu) and wheat (Triticum aestivum cv. IPR Catuara).

\section{Materials and Methods}

The experiments were carried out at the Laboratories of Plant Physiology and Organic Chemistry of the Universidade Federal da Fronteira Sul, Campus of Laranjeiras do Sul, Paraná, Brazil. The methodology used was adapted from the work of An, Pratley and Haig (2001).

\section{Obtaining the aqueous extract}

The shoot biomass of 200 South African lovegrass plants at the end of the reproductive cycle was randomly collected in an invaded pastureland in the municipality of Abelardo Luz, Santa Catarina, Brazil, in April 2015. The plants were manually cut at $1 \mathrm{~cm}$ from the soil surface using scissors, and the sample was kept in a freezer at $-26 \pm 2^{\circ} \mathrm{C}$ until drying. The drying was performed in a forced air circulation oven, at $40^{\circ} \mathrm{C}$ until constant weight in May 2015. Shortly after drying, the sample was ground in a Wiley mill (2 mm grid) and packed in glass jars $(500 \mathrm{~mL})$ with a lid and sealed with plastic film, to avoid increase in moisture.

For the preparation of the South African lovegrass phytomass extract, $25 \mathrm{~g}$ of dry shoots was placed in a glass jar $(500 \mathrm{~mL})$ with a perforated cap $(3 \times 2 \mathrm{~mm}$ holes) to allow gas exchange. Subsequently, $75 \mathrm{~mL}$ of distilled water was added and mixed. The sample was then incubated in a dark room at $20^{\circ} \mathrm{C}$ for 10 days. Moisture was maintained with the daily replacement of the mass of water lost by evaporation.

After incubation, the aqueous extract was obtained by adding $500 \mathrm{~mL}$ of distilled water to the sample. The solution was mixed for $10 \mathrm{~min}$ in an orbital shaker at $200 \mathrm{rpm}$ and $25^{\circ} \mathrm{C}$. The mixture was left to stand for $5 \mathrm{~min}$ at room temperature before filtering with gauze. The filtered solution was centrifuged for 40 min at 3,900 $\mathrm{rpm}$, and the supernatant was passed through a paper filter ( $25 \mu \mathrm{m}$ pores). The volume of recovered aqueous extract was approximately $450 \mathrm{~mL}$, and the decanted material was discarded.

Finally, evaluations of the $\mathrm{pH}$ and electrical conductivity of the aqueous extract of the South African lovegrass shoots phytomass and the distilled water used as control were performed (Table 1). 
Table 1. Physical-chemical characteristics of the aqueous extract of degraded phytomass of Eragrostis plana and distilled water.

\begin{tabular}{|c|c|c|}
\hline Solution & $\mathrm{pH}$ & Electric conductivity [ $\left.\mu \mathrm{S} . \mathrm{m}^{-2} . \mathrm{s}\right]$ \\
\hline Aqueous extract & 7.13 & 735.8 \\
\hline Distilled water & 6.12 & 3.63 \\
\hline
\end{tabular}

\section{Quantification of total phenols}

For the determination of the total phenols, $50 \mathrm{~mL}$ of the aqueous extract was mixed with $150 \mathrm{~mL}$ of acetone. The solution was stirred at low speed $(\sim 15 \mathrm{rpm})$ at room temperature $\left(\sim 22^{\circ} \mathrm{C}\right)$ for $12 \mathrm{~h}$. Proteins and lipids from the supernatant were precipitated and vacuum filtered on two layers of filter paper ( $25 \mu \mathrm{m}$ porosity), and the precipitate was discarded. The acetone was removed from the extract using rotary evaporator at $40^{\circ} \mathrm{C}$. The resulting liquid was washed with three portions of $100 \mathrm{~mL}$ of hexane and then three times with $100 \mathrm{~mL}$ of ether. The phase containing hexane was discarded. The ether phase was dried with a spatula tip of anhydrous sodium sulfate $\left(\mathrm{Na}_{2} \mathrm{SO}_{4}\right)$. The ether was removed with a rotary evaporator at $40^{\circ} \mathrm{C}$, and the residue $(3.49 \mathrm{~g})$ was diluted in $20 \mathrm{~mL}$ of distilled water. The samples were transferred to cuvettes for spectrophotometer reading. The cuvettes consisted of $100 \mu \mathrm{L}$ of the extract, $600 \mu \mathrm{L}$ of $\mathrm{NaCO}_{3}(7.5 \% \mathrm{w} / \mathrm{v}), 700 \mu \mathrm{L}$ of distilled water and $200 \mu \mathrm{L}$ of Folin-Ciocalteau reagent, with this mixture being heated to $50^{\circ} \mathrm{C}$ for 10 min and diluted with 1.0 $\mathrm{mL}$ of distilled water before spectrophotometer reading. The analytical curve for quantification was constructed as a function of concentrations of $0,10,20,30$ and $40 \mu \mathrm{g} \mathrm{mL}^{-1}$ of gallic acid at $760 \mathrm{~nm}$. The phenolic substances present in the evaluated sample were reported in micrograms equivalent of gallic acid per milliliter of aqueous extract of degraded phytomass of E. Plana.

\section{Bioassay of germination}

To assess the effect of the aqueous extract of the incubated dried shoots of South African lovegrass on the germination of target plants, 20 seeds of palisade grass (Urochloa brizantha cv. Marandu), alfalfa (Medicago sativa cv. Monarca) and wheat (Triticum aestivum cv. IPR Catuara) were placed in a Gerbox-type box, in an entirely randomized design with six replicates. One bioassay for each species was carried out, with the aqueous extract and the distilled water constituting the treatments.

The boxes were lined with germinating paper and moistened with $3.7 \mathrm{~mL}$ of aqueous extract or distilled water, the equivalent of a 1:2.5 mass ratio $(\mathrm{w} / \mathrm{w})$. The species were incubated in a growth chamber, at $20 / 35^{\circ} \mathrm{C}$ (night/day) for palisade grass and $20^{\circ} \mathrm{C}$ for alfalfa and wheat, all with a $12: 12 \mathrm{~h}$ light/dark cycle. Fluorescent lamps were used to produce a light intensity of $200 \mu \mathrm{mol} \mathrm{m} \mathrm{m}^{-2} \mathrm{~s}^{-1}$.

The palisade grass germination count began $72 \mathrm{~h}$ after sowing, while for alfalfa and wheat the count started $48 \mathrm{~h}$ after sowing. The counts were performed daily until the stabilization of the germination period when the final evaluation took place following the Brazilian standards for seed analysis (BRASIL, 2009).

The speed of germination was calculated according to the Maguire (1962) equation (Equation 1):

$$
\mathrm{SGI}=(\mathrm{G} 1 / \mathrm{N} 1)+(\mathrm{G} 2 / \mathrm{N} 2)+(\mathrm{G} 3 / \mathrm{N} 3)+\ldots+(\mathrm{Gn} / \mathrm{Nn})[1]
$$

where SGI represents the speed of germination, $\mathrm{Gn}$ is the number of seedlings computed at the first, second, third and last count and $\mathrm{Nn}$ is the number of days of sowing at the first, second, third and final count.

Regression analyses were performed between the percentage of germination of each species and time. Each germination curve was fitted to the Weibull (1951) growth model (Equation 2):

$$
\mathrm{Y}=\mathrm{YM}-(\mathrm{YM}-\mathrm{Y0}) \exp \left\{-1\left[(\mathrm{kX})^{\wedge} \mathrm{g}\right]\right\}[2]
$$

where $Y$ represents the germination, $Y M$ is the point of maximum germination, $Y 0$ is the point of minimum germination, $k$ is the product of division of one by the value of $X$ at the midpoint of $Y$ in the inflection of the curve, $X$ is the time in days and $g$ is the initial value to be adjusted. 
The final germination evaluation was performed for alfalfa, palisade grass and wheat at 9,12 and 7 days after seeding (DAS), respectively.

\section{Bioassay of seedling development}

A total of 1,200 seeds of each species were placed in a growth chamber to germinate and thus to obtain seedlings to assess the effect of the aqueous extract of the incubated dried shoots of South African lovegrass on the seedling development of target plants. The germination paper was moistened with distilled water, the equivalent of a $1: 2.5$ mass ratio (w/w). A temperature alternation of $20 / 35^{\circ} \mathrm{C}$ (night/day) was used for palisade grass, while for alfalfa and wheat, the temperature was constant at $20^{\circ} \mathrm{C}$, all with $12: 12 \mathrm{~h}$ light/dark cycle. Palisade grass seedlings were selected $72 \mathrm{~h}$ after the start of incubation, whereas alfalfa and wheat were collected after $48 \mathrm{~h}$, to standardize seedling length. Palisade grass seedlings with radicles between 5 and $7 \mathrm{~mm}$, alfalfa seedlings with radicle lengths between 10 and $12 \mathrm{~mm}$, and wheat seedlings with radicles between 1 and $3 \mathrm{~mm}$ were selected.

Twenty seedlings of each pre-selected species were arranged in Gerbox-type boxes with two layers of germination paper moistened with distilled water or South African lovegrass aqueous extract, equivalent of a 1:2.5 mass ratio $(\mathrm{w} / \mathrm{w})$. The incubation temperatures and the light cycle were the same as those used for the germination bioassay.

After incubation, the length of the longest root and coleoptile (for palisade grass and wheat) and hypocotyl (for alfalfa) of each plant were measured using calipers. The average of each variable by Gerbox was used for statistical analysis. The experimental design was a completely randomized design with six replicates. Three bioassays were carried out, one for each target species, with the aqueous extract and the distilled water constituting the treatments.

\section{Statistical analysis}

The data was submitted to analysis of variance, and F-test was used to determine the occurrence of a significant difference between the treatments, using the statistical software Genes. For some variables, the standard error of the means were incorporated, to show an estimative of the variability among replicates. Regression analysis was also used to adjust the germination curves over time.

\section{Results}

\section{Quantification of total phenols in Eragrostis plana aqueous extract}

The total phenol amount in solutions is usually indicative of phytotoxicity, with significant quantities linked to high inhibition of plant growth (AN et al., 2001). The concentration of total phenols in the aqueous extract of South African lovegrass was $0.75 \mathrm{~g} \mathrm{~L}^{-1}$. This value is equivalent to $0.75 \mathrm{mg}$ of phenols per $\mathrm{g}$ of shoots dry mass, in other words, $1,000 \mathrm{~g}$ of dry shoots from South African lovegrass can release $0.75 \mathrm{~g}$ of phenols.

\section{Influence of aqueous extract on germination}

The seeds of alfalfa, palisade grass and wheat responded differently to the South African lovegrass aqueous extract. For alfalfa, the treatment with extract differed from the control with distilled water by the Ftest for final germination. The germination, within each treatment, also differed between days after sowing $(p<0.05)$. Alfalfa germination was slowed and fewer seeds germinated with treatment of the extract, when compared with distilled water (Figure 1). 


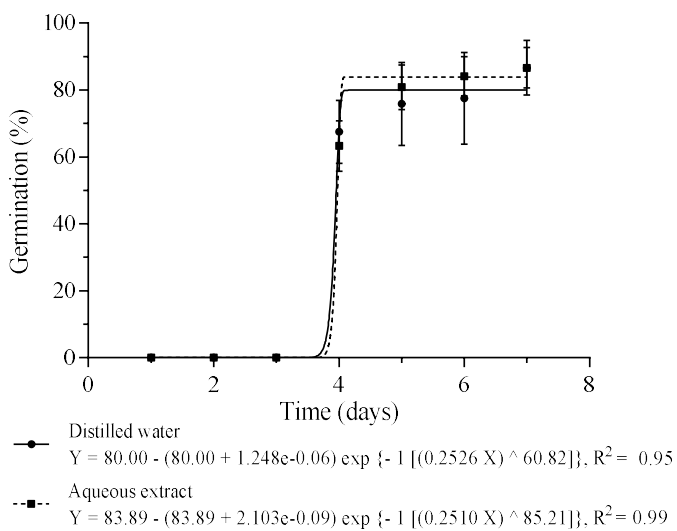

Figure 3. Percentage of accumulated germination of wheat (Triticum aestivum cv. IPR Catuara) after sowing (DAS) in the treatments with distilled water and with aqueous extract of incubated dry shoots mass of Eragrostis plana. The points correspond to the means of the treatments with the standard error bars representing the variability between the repetitions. The curve represents a nonlinear Weibull model, where $\mathrm{Y}$ is the germination (\%), and $\mathrm{X}$ is time (days).

Weibull regression equations were used to determine, by interpolation, the T50 values, which correspond to the time required for each treatment to express $50 \%$ of maximum germination (Table 2 ). The species with the highest sensitivity to the aqueous extract, considering T50, was palisade grass. The time required to T50 with the extract was approximately 13\% lower than the time necessary with distilled water. For the other species, the values of T50 were practically equivalent, evidencing a small influence of the aqueous extract in the germination process.

Table 2. Time in days needed to alfalfa (Medicago sativa cv. Monarca), palisade grass (Urochloa brizantha cv. Marandu) and wheat (Triticum aestivum cv. IPR Catuara) reach $50 \%$ of maximum germination (T50), in the treatments with aqueous extract of Eragrostis plana and distilled water.

\begin{tabular}{ccc}
\hline Species & & Treatment \\
\cline { 2 - 3 } & Distilled water & Aqueous extract \\
\hline Alfalfa & 4.8 & 4.7 \\
Palisade grass & 5.4 & 4.7 \\
Wheat & 4.0 & 4.0 \\
\hline
\end{tabular}

In the final evaluation of germination, however, differences between aqueous extract and distilled water were observed in the variables normal seedlings, mortality, and speed of germination index for alfalfa and abnormal seedlings for palisade grass (Table 3 ). 
Table 3. Percentage of normal and abnormal seedlings, quiescent seeds, mortality and speed of germination index (SGI) in alfalfa (Medicago sativa cv. Monarch), palisade grass (Urochloa brizantha cv. Marandu) and wheat (Triticum aestivum cv. IPR Catuara) as a function of treatment with distilled water or aqueous extract of Eragrostis plana on the 9th, 12th and 7th day after sowing, respectively.

\begin{tabular}{|c|c|c|c|c|c|c|}
\hline Species & Treatment & $\begin{array}{c}\text { Normal } \\
\text { seedlings } \\
{[\%]}\end{array}$ & $\begin{array}{c}\text { Abnormal } \\
\text { seedlings } \\
{[\%]}\end{array}$ & $\begin{array}{c}\text { Quiescent } \\
\text { seeds } \\
{[\%]}\end{array}$ & $\begin{array}{c}\text { Mortality } \\
{[\%]}\end{array}$ & SGI \\
\hline \multirow[b]{2}{*}{ Alfalfa } & Distilled water & $60.00 \pm 3,65^{*}$ & $21.67 \pm 2.11^{\text {nd }}$ & $12.50 \pm 3.82 \mathrm{nd}$ & $5.83 \pm 0.83^{*}$ & $2.44 \pm 0.09$ * \\
\hline & $\begin{array}{l}\text { Aqueous } \\
\text { extract }\end{array}$ & $43.33 \pm 3.33$ * & $25.00 \pm 2.24$ nd & $11.67 \pm 2.11^{n d}$ & $\underset{*}{20.00 \pm 4.83}$ & $1.91 \pm 0.15$ * \\
\hline \multirow{2}{*}{$\begin{array}{l}\text { Palisade } \\
\text { grass }\end{array}$} & Distilled water & $77.50 \pm 3.10^{n d}$ & $5.83 \pm 0.83$ * & $10.83 \pm 1.54 \mathrm{nd}$ & $\underset{\text { nd }}{5.83 \pm 2.39}$ & $\underset{\text { nd }}{2.76 \pm 0.14}$ \\
\hline & $\begin{array}{c}\text { Aqueous } \\
\text { extract }\end{array}$ & $84.17 \pm 3.00$ nd & $0.83 \pm 0.83$ * & $9.17 \pm 2.71$ nd & $\underset{\mathrm{nd}}{5.83 \pm 1.54}$ & $3.21 \pm \underset{\mathrm{nd}}{0.18}$ \\
\hline \multirow{2}{*}{ Wheat } & Distilled water & $86.67 \pm 3.33^{n d}$ & $3.33 \pm 2.11 \mathrm{nd}$ & $3.33 \pm 1.67 \mathrm{nd}$ & $6.67 \pm 2.11$ & $\underset{\mathrm{nd}}{4.03 \pm 0.18}$ \\
\hline & $\begin{array}{c}\text { Aqueous } \\
\text { extract }\end{array}$ & $85.00 \pm 2.58{ }^{\text {nd }}$ & $5.83 \pm 2.39$ nd & $3.33 \pm 1.055^{\text {nd }}$ & $\underset{\mathrm{nd}}{5.83 \pm 1.54}$ & $\underset{\mathrm{nd}}{4.05 \pm 0.12}$ \\
\hline
\end{tabular}

* Values (Average \pm Standard error) in each column and species are significantly different according to F-test ( $p<0.05) ;{ }^{\text {nd }}$ Not different

Distilled water resulted in a higher percentage of normal alfalfa seedlings than aqueous extract. Also, the treatment with distilled water caused a lower occurrence of dead seeds and a higher speed of germination index for alfalfa.

Conversely, for palisade grass, the aqueous extract reduced the occurrence of abnormal seedlings compared with distilled water. There were no significant differences between the treatments on other variables, even with the germination speed index showing a tendency for higher values with aqueous extract than distilled water.

In wheat, there were no significant differences between treatments for all variables. This trait demonstrates an insensitivity to the compounds of the aqueous extract on germination process. The absence of influence of the aqueous extract on wheat diverges from the sensitivity on alfalfa and palisade grass germination (Figure 4).

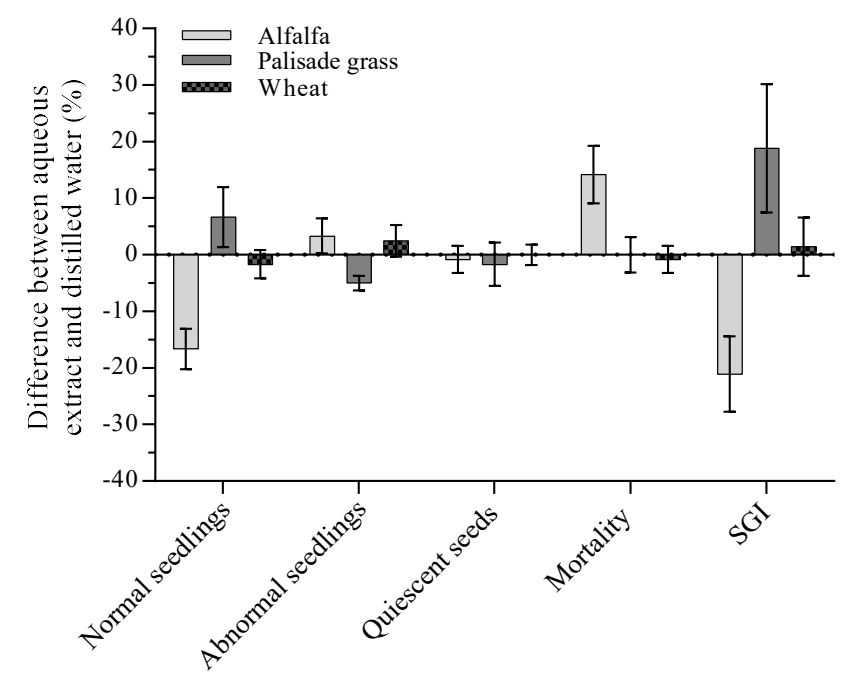

Figure 4. Difference between aqueous extract of Eragrostis plana shoots and distilled water for normal and abnormal seedlings, quiescent seeds, mortality and speed of germination index (SGI) in alfalfa (Medicago sativa cv. Monarca), palisade grass (Urochloa brizantha cv. Marandu) and wheat (Triticum aestivum cv. IPR Catuara) on the 9th, 12th and 7th days after sowing, respectively. The bars correspond to the mean difference in percentage between the values observed in the 
treatments with aqueous extract and distilled water, with the standard error bars representing the variability between the repetitions.

The percentage of normal alfalfa seedlings and the speed germination index of aqueous extracts were 16.7 and 21.1 percentage points lower than distilled water, respectively. Another negative record for alfalfa is related to mortality, which was $14.7 \%$ higher with aqueous extract than distilled water. Palisade grass presented $5 \%$ less abnormal seedlings with extract than with distilled water. Although only with a tendency (not significant difference), the SGI of palisade grass was $18.8 \%$ higher in the extract compared to distilled water.

\section{Influence of aqueous extract on seedling development}

Alfalfa, palisade grass and wheat seedling development were influenced by the South African lovegrass aqueous extract when compared to distilled water (Table 4). The radicle and total lengths of alfalfa seedlings were reduced by the aqueous extract. The seedlings of palisade grass and wheat also showed sensitivity to the aqueous extract, registering values significantly lower than with distilled water for radicle length, total length and dry seedling mass.

Table 4. Radicle length, hypocotyl length, total length and mass from seedlings of alfalfa (Medicago sativa cv. Monarca), palisade grass (Urochloa brizantha cv. Marandu) and wheat (Triticum aestivum cv. IPR Catuara) in function of the treatments distilled water and Eragrostis plana aqueous extract 48 hours after incubation.

\begin{tabular}{cclccc}
\hline Species & Treatment & Radicle length [mm] & Hypocotyl length [mm] & $\begin{array}{c}\text { Total length } \\
\text { [mm] }\end{array}$ & $\begin{array}{c}\text { Seedling mass } \\
\text { [g] }\end{array}$ \\
\hline \multirow{2}{*}{ Alfalfa } & Distilled water & $26.62 \pm 0.93^{*}$ & $4.34 \pm 0.28^{\text {nd }}$ & $30.96 \pm 0.82^{*}$ & $2.25 \pm 0.13^{\text {nd }}$ \\
& Aqueous extract & $21.81 \pm 0.50^{*}$ & $4.10 \pm 0.14$ nd & $25.90 \pm 0.38^{*}$ & $2.47 \pm 0.18^{\text {nd }}$ \\
\hline \multirow{2}{*}{ Palisade grass } & Distilled water & $14.09 \pm 0.47^{*}$ & $21.58 \pm 0.98^{\text {nd }}$ & $35.67 \pm 1.13^{*}$ & $1.77 \pm 0.04^{*}$ \\
& Aqueous extract & $11.76 \pm 0.70^{*}$ & $19.91 \pm 0.61$ nd & $31.67 \pm 0.73^{*}$ & $1.39 \pm 0.09^{*}$ \\
\hline \multirow{2}{*}{ Wheat } & Distilled water & $33.30 \pm 0.83^{*}$ & $11.07 \pm 0.72$ nd & $44.37 \pm 1.50^{*}$ & $3.03 \pm 0.06^{*}$ \\
& Aqueous extract & $29.14 \pm 0.27^{*}$ & $9.65 \pm 0.54$ nd & $38.79 \pm 0.72 *$ & $2.77 \pm 0.06^{*}$ \\
\hline
\end{tabular}

*Values (Average \pm Standard error) in each column and species are significantly different according to F-test ( $p<0.05)$; ${ }^{\text {nd }}$ Not different

In general, the differences between the treatments of aqueous extract and distilled water were more pronounced in seedling development (Figure 5) than in the germination variables. Radicle and total lengths of alfalfa seedlings in the aqueous extract were 17.4 and $15.9 \%$ smaller than in distilled water, respectively. Radicular and total lengths of palisade grass seedlings were also reduced, 16.2 and $10.7 \%$ by the aqueous extract, respectively. Palisade grass seedling dry mass suffered the greatest reduction by the aqueous extract among the evaluated species, registering a value $21.8 \%$ lower than distilled water.

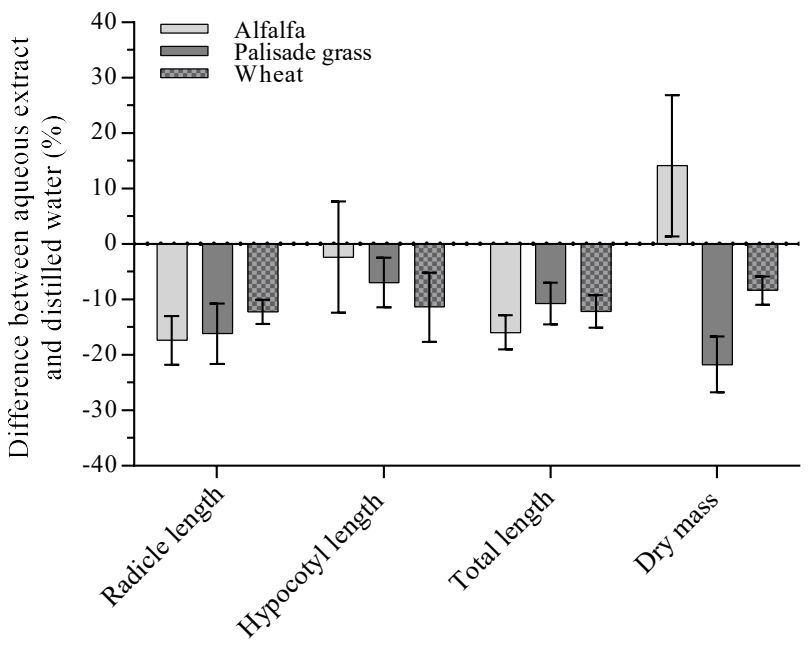


Figure 5. Difference between aqueous extract of Eragrostis plana shoots and distilled water for radicle, hypocotyl and total length and seedling mass in alfalfa (Medicago sativa cv. Monarca), palisade grass (Urochloa brizantha cv. Marandu) and wheat (Triticum aestivum cv. IPR Catuara) 48 hours after incubation. The bars correspond to the mean difference in percentage between the values observed in the treatment with aqueous extract and distilled water with the standard error bars representing the variability between the repetitions.

Wheat seedling development was sensitive to the aqueous extract, unlike germination. The radicular and total lengths of seedlings with aqueous extract were 12.2 and $12.1 \%$ lower than distilled water. The dry mass of wheat seedlings was reduced by $8.4 \%$ in aqueous extracts.

\section{Discussion}

The amount of total phenols in South African lovegrass shoots differed from other plants. For instance, the total phenol was nearly five times higher than detected in vulpia phytomass (Vulpia myuros), which was approximately $0.15 \mathrm{~g} \mathrm{~L}^{-1}$ using similar methodology for extraction (AN et al., 2001). The amount of total phenols in South African lovegrass aqueous extract was also 3.3 times higher than the mean of the values recorded for the aqueous extract of sorghum leaves (Sorghum bicolor) (BEN-HAMMOUD et al., 1995). When compared to other species, the high amount of phenols obtained by the incubation and extraction process indicates that South African lovegrass stores a high quantity of phenolic compounds in its shoots.

The different responses to the aqueous extract on the germination process between the target species are justifiable since the sensitivity and reaction of the seeds to the compounds are expected to be variable among plant species and family (ALMAGHRABI, 2012). For example, some species may present tolerance to the aqueous extract compounds. Also, some seeds have a more developed or distinct tegument composition, which acts as a protective tissue controlling the flow of substances into the embryo through selective permeability. Similar results of those observed in the water extracts on alfalfa were obtained testing South African lovegrass aqueous extracts on white clover (FAVARETTO et al., 2011).

Furthermore, some phenolic compounds of the extract may act in synergy with certain plant hormones, promoting an increase of germination and tissue growth, while others may act negatively by causing the decarboxylation of auxins (MACÍAS et al., 2004) or by binding to gibberellic acid (ISHIKURA et al., 2001).

Similar results to wheat seedling development were reported using sorghum aqueous extract, with the phenolic acids explaining the reduction of radicle size (BEN-HAMMOUDA et al., 1995). Phenolic compounds present in the aqueous extract of Allium ursium have also been shown to be responsible for the reduction of wheat seedling radicle lengths (DJURDJEVIC et al., 2004). In summary, the influence of the aqueous extract of South African lovegrass phytomass differed between the target species and the stage of development (Table 5).

Table 5. Negative (-), neutral (0) or positive (+) influence of the aqueous extract of Eragrostis plana biomass, incubated for 10 days, on alfalfa (Medicago sativa cv. Monarca), palisade grass (Urochloa brizantha cv. Marandu) and wheat (Triticum aestivum cv. IPR Catuara) seeds and seedlings variables compared with distilled water

\begin{tabular}{ccccc}
\hline \multirow{2}{*}{ Stage of development and variable } & \multicolumn{3}{c}{ Species } \\
\cline { 3 - 5 } Seed & Germination & Alfalfa & Palisade grass & Wheat \\
\hline \multirow{3}{*}{ Seedling } & Abnormal germination & - & 0 & 0 \\
& Mortality & 0 & + & 0 \\
& Speed of germination index & - & 0 & 0 \\
& Radicle length & - & 0 & 0 \\
\hline & Hypocotyl length & 0 & - & - \\
& Total length & - & - & - \\
\hline
\end{tabular}


It should be emphasized that the aqueous extract had greater effect on the development of seedlings than on germination. This feature may be justified by the presence of the integument in the seeds. Besides acting as a barrier, the coating may protect the embryo from the phytotoxic effect of chemical compounds by not allowing it to reach the embryonic tissue (ARAÚJO \& MONTEIRO, 2005). Unlike germination, seedling development occurs without such protective structures, meaning it is a stage of development more susceptible to environmental adversities.

The variables that suffered the greatest reductions due to the aqueous extract were radicle and total lengths. Perhaps since the radicle is the first tissue to come into contact with the chemical compounds of the extract, there is a greater inhibition of this tissue in relation to the hypocotyl (alfalfa) and coleoptile (wheat and palisade grass). As the extract did not influence the hypocotyl and coleoptile lengths, the reduction on the radicle may also have contributed to the decrease in the total seedling lengths in the aqueous extract compared to distilled water.

The South African lovegrass shoots aqueous extract presented a total phenols concentration of $0.75 \mathrm{~g}$ $\mathrm{L}^{-1}$ which corresponds to $1.35 \%$ of the shoots dry mass after a ten-day incubation. The effect on germination varied according to the target species: alfalfa (Medicago sativa cv. Monarca) was negatively affected, palisade grass (Urochloa brizantha cv. Marandu) was positively affected, and wheat (Triticum aestivum cv. IPR Catuara) presented insensitivity.

However, all target species were negatively affected by aqueous extract of South African lovegrass shoots on seedling development. The results highlighted allelopathy in the study of ecological interactions between South African lovegrass and other plant species. It can also be assumed that allelopathy can be used by the species in its process of agroecosystems invasion.

\section{Conclusions}

The aqueous extracts of $E$. plana showed presence of total phenols, a class of chemical compounds with potential to cause toxicity in target plants.

The germination and speed of gemination of alfalfa was reduced by $E$. plana aqueous extract.

The aqueous extract of $E$. plana interfered in the radicle growth of all species evaluated but did not influence the hypocotyl. This evidences differential sensitivity between the tissues of the target plants and indicates the site of action of the extract compounds in seedlings.

\section{Acknowledgements}

The supports received from the Brazilian National Council for Scientific and Technological Development, the Brazilian Coordination for the Improvement of Higher Education Personnel, the Federal University of Fronteira Sul, and the Federal Technological University of Parana are appreciated.

\section{References}

AL HARUN, M.A.Y.; JOHNSON, J.; UDDIN, M.D.N.; ROBINSON, R.W. Identification and Phytotoxicity Assessment of Phenolic Compounds in Chrysanthemoides monilifera subsp. monilifera (Boneseed). PLOS ONE, v. 10, n. 10, p. e0139992, 2015.

ALMAGHRABI, O.A. Control of wild oat (Avena fatua) using some phenolic compounds I - Germination and some growth parameters. Saudi Journal of Biological Sciences, v. 19, n. 1, p. 17-24, 2012.

AN, M.; PRATLEY, J.E.; HAIG, T. Phytotoxicity of vulpia residues: IV. Dynamics of allelochemicals during decomposition of vulpia residues and their corresponding phytotoxicity. Journal of Chemical Ecology, v. 27, n. 2, p. 395-409, 2001.

ARAÚJO, A.S.F.; MONTEIRO, R.T.R. Plant bioassays to assess toxicity of textile sludge compost. Scientia Agricola, v. 62, n. 3, 2005.

BEN-HAMMOUDA, M.L.A.; MONCEF, R.J.K.; MINOR, H.C. Phytotoxicity of extracts from sorghum plant components on wheat seedlings. Crop Science, v. 35, n. 6, p. 1652-1656, 1995. 
BITTENCOURT, H.V.H.; BONOME, L.T.S.; TREZZI, M.M.; VIDAL, R.A.; LANA, M.A. Seed germination ecology of Eragrostis plana, an invasive weed of South American pasture lands. South African Journal of Botany, v. 109, p. 246-252, 2017.

BRASIL. Regras para análises de sementes. Brasília: SNDA/DNDV/CLAV, 2009.

CHOU, C.H.; LEU, L.L. Allelopathic substances and interactions of Delonix regia (Boj) Raf. Journal of Chemical Ecology, v. 18, n. 12, p. 2285-2303, 1992.

CLAYTON, W.D.; VORONTSOVA, M.S.; HARMAN, K.T.; WILLIAMSON, H. GrassBase - The Online World Grass Flora. 2006. Disponível em: <http://www.kew.org/data/grasses-db.html>. Acesso em: 17 maio. 2015.

DJURDJEVIC, L.; DINIC, A.; PAVLOVIC, P.; MITROVIC, M.; KARADZIC, B.; TESEVIC, V. Allelopathic potential of Allium ursinum L. Biochemical Systematics and Ecology, v. 32, n. 6, p. 533-544, 2004.

FAVARETTO, A.; SCHEFFER-BASSO, S.M.; FELINI, V.; ZOCH, A.N.; CARNEIRO, C.M. Growth of white clover seedlings treated with aqueous extracts of leaf and root of tough lovegrass. Revista Brasileira de Zootecnia, v. 40, n. 6, p. 1168-1172, 2011.

FAVARETTO, A.; SANTOS, J.; CARNEIRO, C.M.; SCHEFFER-BASSO, S.M. The first anatomical and histochemical study of tough lovegrass (Eragrostis plana Nees, Poaceae). African Journal of Agricultural Research, v. 10, n. 30, p. 2940-2947, 2015.

FERREIRA, N.R.; MEDEIROS, R.B.; FAVRETO, R. Banco de sementes do solo de margem viária dominada por capim-annoni-2 e sujeito ao controle com distúrbios no solo e introdução de gramíneas. Revista Brasileira de Sementes, v. 30, n. 3, p. 54-63, 2008.

HIERRO, J.L.; CALLAWAY, R.M. Allelopathy and exotic plant invasion. Plant and Soil, v. 256, n. 1, p. 29-39, 2003.

INDERJIT. Plant phenolics in allelopathy. The Botanical Review, v. 62, n. 2, p. 186-202, 1996.

ISHIKURA, Y.; KOJIMA, Y.; TERAZAWA, M. Effects of Phenolic Compounds on Seed Germination of Shirakamba Birch, Betula platyphylla var. japonica. Eurasian Journal of Forest Research, n. 2, p. 17-25, 2001.

LI, Z.H.; WANG, Q.; RUAN, X.; PAN, C.; JIANG, D. Phenolics and Plant Allelopathy. Molecules, v. 15, n. 12, p. 8933-8952, 2010.

MACÍAS, F.A.; GALINDO, J.C.G.; MOLINILLO, J.M.G.; CUTLER, H.G. Allelopathy: Chemistry and mode of action of allelochemicals. Boca Raton: CRC Press, 2004.

MACÍAS, F.A.; MOLINILLO, J.M.G.; VARELA, R.M.; GALINDO, J.C.G. Allelopathy - A natural alternative for weed control. Pest Management Science, v. 63, n. 4, p. 327-348, 2007.

MAGUIRE, J.D. Speed of Germination - Aid In Selection And Evaluation for Seedling Emergence And Vigor. Crop Science, v. 2, n. 2, p. 176, 1962.

TAIZ, L.; ZEIGER, E.; MØLLER, I.M.; MURPHY, A. Fisiologia e desenvolvimento vegetal. 6th. ed. Porto Alegre: Artmed, 2017.

WEIBULL, W.A. statistical distribution function of wide applicability. Journal of Applied Mechanics, v. 8, n. 1, p. 293-297, 1951.

ZENNI, R.D.; ZILLER, S.R. An overview of invasive plants in Brazil. Brazilian Journal of Botany, v. 34, n. 3, p. 431-446, 2011. 